\title{
Kronik Hemodiyaliz Hastalarında Vankomisin Dirençli Enterokok Kolonizasyonu için Risk Faktörlerinin Belirlenmesi
}

\section{Determination of Risk Factors for the Colonization of Vancomycin Resistant Enterecocci in Chronic Hemodialysis Patients}

\author{
Cemile ÇERMELil(IDD), Zeynep TÜRE²(IDD), Gamze KALIN ÜNÜVAR²(IDD), Ayșegül ULU KILIÇ²(IDD) \\ ${ }^{1}$ Erciyes Üniversitesi Tıp Fakültesi Hastanesi, Kardiyoloji Klinig̃i, Kayseri, Türkiye \\ ${ }^{2}$ Erciyes Üniversitesi Tıp Fakültesi, İnfeksiyon Hastalıkları ve Klinik Mikrobiyoloji Anabilim Dalı, Kayseri, Türkiye
}

Makale atıfı: Çermeli C, Türe Z, Kalın Ünüvar G, Ulu Kılıç A. Kronik hemodiyaliz hastalarında vankomisin dirençli enterokok kolonizasyonu için risk faktörlerinin belirlenmesi. FLORA 2021;26(1):208-15.

\section{ÖZ}

Giriş: Hastane ortamında kolonize olan vankomisine dirençli Enterokoklar (VRE) kuru yüzeylerde uzun süre canlı kalabilmeleri nedeniyle sağlık personelinin elleri ve çevreye temas yoluyla kolayca yayılabilir. Çalısmamızda nefroloji kliniğinde takip edilen, kronik hemodiyaliz hastalarında VRE kolonizasyonu gelişmesindeki risk faktörlerinin belirlenmesi amaçlandı.

Materyal ve Metod: Bu çalışma hastane Infeksiyon Kontrol Komitesi sürveyans takip formu ve hastane otomasyon sistemi bilgileri kullanılarak retrospektif olarak yapıldı. Hastaların demografik verileri, komorbiditeleri, immunsüpresyon, antibiyotik kullanım öyküsü ve kullanılan antibiyotikler, VRE kolonizasyonu açısından riskli servislerde yatış öyküsü, servisler arası transfer öyküsü ve VRE kolonizasyonu ya da infeksiyonu olan hasta ile aynı serviste yatıs öyküsü varlığı kaydedildi. VRE ile kolonize olan hastalar vaka; aynı dönem içinde takip edilen ve kolonize olmayan hastalar kontrol grubu kabul edildi. Çoklu lojistik regresyon analizinde vaka ve kontrol grubu arasında anlamlı olarak fark bulunan parametreler risk faktörü olarak kabul edildi.

Bulgular: Çalışmaya 64 vaka ve 72 kontrol grubu olmak üzere toplam 136 hasta dâhil edildi. Riskli servislerde yatış öyküsü $(p=0.003)$, servisler arasında transfer öyküsü varlığı $(p=0.001)$, VRE kolonize ya da infekte hastalarla aynı serviste bulunma $(p=0.006)$, ve antibiyotik kullanım öyküsü $(p=0.004)$ tek değişkenli analizde anlamlı bulundu. Çoklu lojistik regresyon analizi sonucunda ise, servisler arası transfer öyküsü varlı̆ı $(\beta=3.258$ (\%95 GA 1.65-9.05) p=0.002), VRE'li hasta ile aynı dönemde serviste yatış öyküsünün olması ( $\beta=$ 2.80 (\%95 GA 1.33-5.87) $p=0.006$ ) ve VRE kolonizasyonu öncesi antibiyotik kullanım öyküsünün varlı̆ı ( $\beta=3.21$ (\%95 GA 1.45 7.12) $p=0.004$ ) VRE kolonizasyonu için risk faktörü olarak bulundu.

Sonuç: Uzun süreli ve gereksiz antibiyotik kullanımı enterokoklarda vankomisine karşı direnç gelişmesine neden olabilir. Bu yüzden antibiyotik kullanımında dikkatli olunmalıdır. VRE'li hasta ile aynı serviste yatma ve servisler arası transfer de VRE kolonizasyonu için risk faktörüdür. Infeksiyon kontrolü ve gerekli izolasyon önlemlerine uyulması bu riskin azaltılması için önemlidir.

Anahtar Kelimeler: VRE; Hemodiyaliz; Risk faktörü; Kolonizasyon

Geliș Tarihi/Received: 24/02/2020 - Kabul Ediliș Tarihi/Accepted: 02/06/2020 


\title{
ABSTRACT \\ Determination of Risk Factors for the Colonization of Vancomycin Resistant Enterecocci in Chronic Hemodialysis Patients
}

\author{
Cemile ÇERMELi', Zeynep TÜRE², Gamze KALIN ÜNÜVAR², Ayșegül ULU KILIÇ²
}

\author{
${ }^{1}$ Clinic of Cardiology, Erciyes University Faculty of Medicine Hospital, Kayseri, Turkey \\ 2 Department of Infectious Diseases and Clinical Microbiology, Erciyes University Faculty of Medicine, Kayseri, Turkey
}

Introduction: Vancomycin resistant Enterococci (VRE), can survive on dry surfaces for a long time, easily spread through contact with the hands of healthcare professionals and the environment. In this study, we aimed to determine the risk factors for the development of VRE colonization in chronic hemodialysis patients in the nephrology clinic.

Materials and Methods: This study was conducted retrospectively using Hospital Infection Control Committee surveillance follow-up form and hospital automation system. Demographic data, comorbidities, immunosuppression, antibiotic use history, and antibiotics, hospitalization history in risky services, transfer history between services, and presence of a history of hospitalization with the patient with VRE colonization or infection were recorded. Patients colonized with VRE were accepted as the case and patients who were followed up in the same period and not colonized were accepted as the control group.

Results: A total of 136 patients (64 cases and 72 control groups) were included into the study. As a result of multiple logistic regression analysis, the presence of transfer history between services $(\beta=3.258(95 \% \mathrm{Cl} 1.65-9.05) p=0.002)$, having a history of hospitalization in the same period with the patient with VRE $(\beta=2.80(95 \% \mathrm{Cl} 1.33-5.87) p=0.006)$ and presence of a history of antibiotic use before VRE colonization $(\beta=3.21$ ( $95 \% \mathrm{Cl} 1.45-7.12) p=0.004$ ) were found to be the risk factors for VRE colonization.

Conclusion: Prolonged and unnecessary use of antibiotics may cause resistance to vancomycin in enterococci. Therefore, caution should be exercised in the use of antibiotics. Hospitalization with VRE patient and transfer between services are also risk factors for VRE colonization. Infection control and compliance with necessary isolation measures are important to reduce this risk.

Key Words: VRE; Hemodialysis; Risk factor; Colonization

\section{Giriș}

Enterokoklar normal intestinal floranın non-patojenik elemanı olan gram-pozitif kok yapısında bakterilerdir ${ }^{[1]}$. Son yllarda hastane kökenli gram-pozitif infeksiyon etkenlerinin önemli bir kısmını olușturmaktadırlar. 1986 yilında ilk kez bildirilen vankomisine dirençli enterokok (VRE) infeksiyonu sonrası bu bakteriye bağlı hastane kökenli salgilar sıklıkla bildirilmiștir ${ }^{[2]}$. Enterokoklarda antibiyotik direnci doğal dirençli sușların dıșında yeni direnc genlerinin kazanılması ve gen mutasyonlar1 ile olmaktadir ${ }^{[2]}$. Enterokoklarda vankomisin türü glikopeptid direnci özellikle Enterococcus faecium izolatlarında görülmekle birlikte Enterococcus faecalis ve diğer izolatlarda da sıklğğ giderek artmaktadir ${ }^{[3]}$

Hastane ortaminda kolonize olan VRE'ler cansız yüzeylerde uzun süre canlı kalabilmeleri nedeniyle sağlık personelinin elleri ve kullanılan ekipmanlar yoluyla hastalara kolayca bulașabiliri ${ }^{[4]}$.
VRE'ler özel hasta gruplarında kolonize olarak invaziv infeksiyonlar için risk olușturmaktadır. İleri yas, ko-morbid hastalıkların varlığı, hastane içi transferler, evde bakım hizmeti alımı, uzun süreli hastanede yatıs öyküsü, santral venöz keteterizasyon, üretral kateterizasyon, hematolojik malignite ve tümörler, hemodiyaliz hastaları, vankomisin, 3. kusak sefalosporin ve anti-anaerob antibiyotik kullanımı bașlıca risk faktörleri arasındadır ${ }^{[5-7]}$. Bu nedenle kolonizasyon ve sonrasında gelișen infeksiyonlar genis spektrumlu antibiyotiklerin cok kullanıldığı ve hastanede yatıș sürelerinin uzun olduğu yoğun bakımlar ve hematoloji, onkoloji kliniklerinde daha sı görülmektedir ${ }^{[8,9]}$. VRE'nin etken olduğu infekte hastaların kolonizasyon oranlarına bakıldığında bu oranın \%50'nin üzerinde olduğu görülmüștür ${ }^{[4]}$. VRE ile kolonizasyon ve sonrasında gelisen infeksiyonlarda hastalara uygulanan tedaviler ve hastanede yatıs süresinde uzama olması nedeniyle mortalite dișında tedavi ve hastane maliyetinde de artıs olmaktadır ${ }^{[8]}$. 
Ülkemizde de VRE infeksiyonları, 2000'li y1ların sonrasında görülmeye bașlamıs ve bazı merkezlerde salgınlara yol açmıstır ${ }^{[10,11]}$. Ülkemizden bildirilen vaka serilerinde bildirilen mortalite oranları \%50 ile \%87 arasında değișmektedir ${ }^{[4,12]}$. Ancak bildirilen vaka serilerinde toplam vaka saylar1 20'yi geçmemektedir.

Hastanemiz eriskin nefroloji servisi de nefroloji 1 ve 2 servisi olmak üzere yaklașik 60 hasta kapasitesi olan ve hasta yoğunluğunun cok fazla olduğu bir bölümdür. Bu nedenle bu hasta grubunda VRE kolonizasyonu için risk faktörlerinin belirlenmesi amaçlanmıștır.

\section{MATERYAL ve METOD}

$\mathrm{Bu}$ çalıșma, nefroloji servisinde 2016-2018 yılları arasında yatmıs olan kronik hemodiyaliz hastalarında retrospektif olarak yapıldı. Hastaların bilgileri İnfeksiyon Kontrol Komitesi hasta kartlarindan ve hastane otomasyon sisteminden elde edildi.

Hastalardan İnfeksiyon Kontrol Komitesi programı gereğince ilk 48 saatte ve haftada bir rektal sürüntü örneği alınarak VRE kolonizasyon taraması yapild.

Hastaların demografik ve diğer verileri sürveyans takip formu ve hastane otomasyon bilgi sisteminden alınd. Bu veriler içinde; yas, cinsiyet, hastanede kalma süresi, malinite varlığı, $\mathrm{KOAH}$, diyabet, hipertansiyon, immunsupresyon enteral ve parenteral beslenme varlı̆̆ı, geçirilmis intraabdominal cerrahi öyküsü, travma, H2 reseptör blokeri kullanımı, yanık, immünsupresif ilac kullanımı gibi risk faktörleri kaydedildi. Hastaya yapılan üriner kateterizasyon, hemodiyaliz varlığ1 ve türü, santral keteter varlığı ve yeri, nazogastrik sonda varlığı gibi girișimsel ișlemlerin varlığ

Hastaların hastaneye yatıs tanıları anemi, infeksiyonlar, fistül-kateter uygulamaları, oral alım bozukluğu, renal replasman tedavisi, tromboz ve diğer olarak sınıflandırıldı. İnfeksiyon tanısı ile takip edilen hastalar diyabetik ayak infeksiyonu, fistül infeksiyonu, idrar yolu infeksiyonu, kateter infeksiyonu, peritonit, pnömoni ve yumusak doku infeksiyonu olarak alt gruplara ayrild.

Hastaların kolonizasyon öncesi antibiyotik kullanım öyküleri, ve kullanılan antibiyotikler kayde- dildi. VRE kolonizasyonu açısından riskli alanlar VRE insidansı yüksek olduğu için riskli kabul edilen servislerde yatış öyküsü olanlar, servisler arası transfer öyküsü ve VRE kolonizasyonu ya da infeksiyonu olan hasta ile aynı serviste yatıs öyküsü kaydedildi.

Perirektal sürüntü kültür taraması sonucunda kolonizasyon risk faktörleri açısından VRE kolonizasyonu pozitif grupla negatif grup karsslastıtırld.

VRE identifikasyonunda perirektal bölgeden alınan sürüntü kültürleri için chrom ID VRE agar (bioMŭrieux, Marcy l'Etoile, Fransa) kullanıldi. VRE pozitifliğinden süphelenilen örnekler API Rapid ID 32 STREP kit (bioMŭrieux) kullanilarak ayrıștırldd. Vankomisin ve Teikoplanin direnci E-testi (AB Biodisk, Solna, İsviçre)ile "Clinical and Laboratory Standards Institute (CLSI)" kriterlerine göre yapildl ${ }^{[13]}$.

VRE kolonizasyonu pozitif tespit edilen hastalar vaka; negatif olanlar kontrol grubu olarak belirlendi. Kronik hemodiyaliz hastalarında, VRE kolonizasyonu pozitif olanlar ve VRE kolonizasyonu negatif olan hastalar karșlaștırılarak, VRE kolonizasyonu için risk farktörleri belirlendi.

\section{İstatistiksel Değerlendirme}

Veriler SPSS 22.0 (SPSS Inc Chicago, IL, USA) istatistik paket programında değerlendirildi. Nitel değisskenlerin karşılaștırılması analizi için Ki-kare ve Fischer exact testi kullanıld. Nicel değișkenlerde ise normal dağılım göstermeyen değiskenler için Mann Whitney U testi kullanıldı. Anlamlı değiskenler coklu lojistik regresyon analizi ile değerlendirildi (confidence interval, CI \%95). $p<0.05$ değeri istatistiksel olarak anlamlı kabul edildi.

$\mathrm{Bu}$ calıșma için Erciyes Üniversitesi Klinik araștırmalar Etik Kurulu'ndan 12.01.2001 tarihinde 2018/01 numarasiyla onay alındı.

\section{BULGULAR}

Calıșmaya 64 vaka ve 72 kontrol grubu olmak üzere toplam 136 hasta dahil edildi. Demografik veriler, ko-morbitide, risk faktörleri ve kullanilan antibiyotiler açısından vaka ve kontrol grubunun karșlaștırılması Tablo 1'de gösterilmiștir. Buna göre yaș, cinsiyet, ve hastanede yatıs süreleri aç1sindan VRE kolonize olan ve olmayan grup ara- 


\begin{tabular}{|c|c|c|c|c|}
\hline & $\begin{array}{c}\text { Vaka Grubu } \\
\text { n (\%) }\end{array}$ & $\begin{array}{c}\text { Kontrol Grubu } \\
\text { n (\%) }\end{array}$ & $\mathbf{p}$ & $\begin{array}{c}\text { Çok Değişkenli Analiz } \\
\text { p OR }(95 \% \mathrm{Cl})\end{array}$ \\
\hline Hasta sayısı & 64 & 72 & & \\
\hline Kadın Cinsiyet & $34(\% 53.1)$ & $42(\% 58.3)$ & 0.605 & \\
\hline Yaş Median (min-maks) & $64(50-74)$ & $60(51-70)$ & 0.454 & \\
\hline \multicolumn{5}{|l|}{ Yaş grupları } \\
\hline 65 yaş ve altı & $34(53.1)$ & $42(58.3)$ & 0.541 & \\
\hline 66 yaş ve üstü & $30(46.9)$ & $30(41.7)$ & & \\
\hline Yatış süresi Median (min-maks) & $6(4-12)$ & $7(5-12)$ & 0.131 & \\
\hline \multicolumn{5}{|l|}{ Ko-morbiditeler } \\
\hline Malignite & $1(1.5)$ & $6(8.3)$ & 0.029 & \\
\hline $\mathrm{KOAH}$ & $6(9.4)$ & $9(12.5)$ & 0.76 & \\
\hline $\mathrm{HT}$ & $46(72)$ & $54(75)$ & 0.82 & \\
\hline $\mathrm{DM}$ & $31(48.4)$ & $24(33)$ & 0.82 & \\
\hline KKY & $3(4.7)$ & $18(25)$ & 0.002 & \\
\hline \multicolumn{5}{|l|}{ Risk Faktörleri } \\
\hline Transfüzyon & $32(50)$ & $25(35)$ & 0.083 & \\
\hline TPN & $3(3.1)$ & $3(4.2)$ & 0.999 & \\
\hline Kronik steroid kullanımı & $4(6.3)$ & $4(5.6)$ & 0.999 & \\
\hline Diyare & $1(1.6)$ & $2(2.8)$ & 0.999 & \\
\hline Riskli servislerde yatış öyküsü & $41(61.4)$ & $28(38.9)$ & 0.003 & \\
\hline VRE'li hasta ile aynı serviste yatma öyküsü & $41(64.1)$ & $29(40.3)$ & 0.006 & $0.0062 .80(1.33-5.87)$ \\
\hline Servisler arası transfer & $24(37.5)$ & $9(12.5)$ & 0.001 & $0.0023 .258(1.65-9.05)$ \\
\hline Antibiyotik kullanımı öyküsü & $46(72)$ & $34(47)$ & 0.003 & $0.0043 .21(1.45-7.12)$ \\
\hline Penisilin & $18(28)$ & $12(17)$ & 0.161 & \\
\hline Karbapenem & $12(19)$ & $11(15.3)$ & 0.757 & \\
\hline Kinolon & $10(15.6)$ & $8(11)$ & 0.602 & \\
\hline Sefalosporin & $13(20.3)$ & $9(12.5)$ & 0.316 & \\
\hline Glikopeptit & $20(31.3)$ & $15(21)$ & 0.234 & \\
\hline Aminoglikozit & $1(1.6)$ & $3(4.2)$ & 0.622 & \\
\hline Makrolit & $1(1.6)$ & $4(5.6)$ & 0.023 & \\
\hline
\end{tabular}

KOAH: Kronik obstrüktif akciğer hastalığı, HT: Hipertansiyon, DM: Diyabetes mellitus, KKY: Konjestif kalp yetmezliği, TPN: Total parenteral nutrisyon, VRE: Vankomisine dirençli enterokok.

sında istatistiksel olarak anlamalı fark izlenmedi. Hastaların komorbiditeleri açısından karșılaștırma yapıldığında her iki grupta da en sık görülen komorbidite hipertansiyondu. VRE kolonizasyonu olmayan hastaların altısinda (\%8) en az bir malinite varlığ1 mevcutken VRE ile kolonize olan grupta bir hastada malinite izlendi $(\mathrm{p}=0.029)$. Kontrol grubundaki hastaların \%25'inde konjestif kalp yetmezliği mevcutken vaka grubunda bu oran \%5'ti. Konjestif kalp yetmezliği açısından gruplar arasındaki fark istatistiksel olarak anlamlı bulundu ( $p=0.002)$. Kronik obstrüktif akciğer hastalı̆̆1, hipertansiyon, diyabet varlığı açısından gruplar arasında anlamlı fark izlenmedi.

Vaka ve kontrol grubunun risk faktörlerine göre kıyaslaması yapıldığında immunosupresyon varlığı, 
Tablo 2. Vaka ve kontol grubunun yatış tanısı açısından karşılaştırılması

\begin{tabular}{lcc} 
& $\begin{array}{c}\text { Vaka Grubu }(\mathbf{n}=64) \\
\mathbf{n}(\%)\end{array}$ & $\begin{array}{c}\text { Kontrol Grubu }(\mathbf{n}=\mathbf{7 2}) \\
\mathbf{n}(\%)\end{array}$ \\
\hline $\begin{array}{l}\text { Anemi } \\
\begin{array}{l}\text { Infeksiyon } \\
\quad \text { Diyabetik ayak ve yumuşak doku infeksiyonu }\end{array}\end{array}$ & $4(1.4)$ & \\
$\quad$ Fistül infeksiyonu & & $33(51.6)$ \\
$\quad$ Üriner sistem infeksiyonu & $23(31.9)$ & \\
$\quad$ Kateter infeksiyonu & & \\
$\quad$ Peritonit & & $14(21.9)$ \\
$\quad$ Pnömoni & & $3(4.7)$ \\
Fistül ve katater uygulaması & $17(23.6)$ & $3(4.7)$ \\
Oral alım bozukluğu & $5(6.9)$ & $1(1.6)$ \\
Renal replasman & $20(27.8)$ & $5(7.8)$ \\
Tromboz & $2(2.8)$ & \\
Diğer & $4(5.6)$ &
\end{tabular}

transplantasyon öyküsü, transfüzyon öyküsü, total parenteral nütrisyon (TPN) uygulaması, kronik streroid kullanımı ve diyare öyküsü açısından VRE kolonizasyonu pozitif ve negatif gruplar arasında istatistiksel olarak fark izlenmedi. VRE insidansı yüksek olduğu için riskli kabul edilen servislerde yatıs öyküsü varlığı VRE kolonizasyonu olan grupta, olmayan gruba göre anlaml oranda daha yüksekti $(p=0.003)$. VRE kolonize ya da infekte hastalarla aynı serviste bulunma öyküsü VRE kolonize olan grupta, olmayan gruba göre daha yüksek bulundu $(p=0.006)$. Benzer sekilde servisler arasinda transfer öyküsünün bulunması da VRE kolonizasyonu pozitif olan grupta daha yüksekti $(p=0.001)$. Daha öncesinde herhangi bir antibiyotik kullanım öyküsünün bulunması da VRE kolonize hastalarda kontrol grubuna istatistiksel olarak anlamlı oranda yüksek bulundu $(p=0.003)$. Kullanılan antibiyotik gruplarına göre grupların karșılaștırılması yapıldığında her iki grupta da en sık kullanılan antibiyotik grubunun glikopeptidler olduğu tespit edildi. VRE kolonizasyonu pozitif olan grupta makrolid kullanım süresinin daha uzun olduğu görüldü $(p=$ 0.023). Tek değișkenli analiz sonucunda anlamlı cıkan parametreler için cok değișkenli analiz yapıldığında VRE ile infekte ya da kolonize hasta ile aynı serviste yatma, servisler arası transfer ve antibiyotik kullanım öyküsünün varlığı VRE kolonizasyonu için risk faktörü olarak bulundu.

Vaka ve kontrol grubunun hastaneye yatıș tanıları açısından karșılaștırılması Tablo 2'de gö- rülmektedir. Buna göre yatıș tanıları yedi gruba ayrıldı. Hastaların yatıș tanısında infeksiyon hem vaka hem de kontol grubunda en fazla görülen tanıydı. Vaka grubunda ikinci görülen tanı renal replasman iken kontrol grubunda fistuil ve kateter uygulaması olarak belirlendi.

\section{TARTIȘMA}

$\mathrm{Bu}$ çalıșmada yas, cinsiyet, komorbiditeler, TPN ve transfüzyon gibi riskli ișlemler VRE kolonizasyonu açısından anlamlı bulunmamıștır. Buna karșllı antibiyotik kullanım öyküsü, VRE kolonize ya da infekte hasta ile aynı serviste yatma ve servisler arası transfer öyküsünün bulunması VRE kolonizasyonu için anlamlı bulunmustur. Cok merkezli 5117 hasta içeren prospektif bir calıșmada VRE'nin de içinde bulunduğu cok ilaca dirençli bakterilerle kolonizasyonu değerlendirildiğinde antibiyotik kullanım öyküsünün olması, hastanede yatış öyküsünün bulunması, üriner kateter bulunması ve Asya ve Avrupa ülkelerine seyahat öyküsünün bulunması risk faktörleri olarak belirlenmiștir ${ }^{[14]}$. Cerrahi yoğun bakım ünitesinde yapılan bir calıșmada 374 hastada prospektif olarak VRE kolonizasyonu için risk raktörleri değerlendirilmiștir. Calıșma sonucunda YBÜ'de 14 günden fazla kalma, uzun süreli hemodiyaliz uygulaması, kinolon grubu antibiyotik kullanım öyküsü ve piperasilin tazobaktam kullanımının VRE kolonizasyonu riskini arttırdığı tespit edilmiștir[15]. Yüz yetmiș dört erișikin hastada VRE kolonizasyonu için risk faktörlerinin değerlendirildiği bir çalıșmada 65 yaș üzeri olmak, 
hastanede kalıs süresinin yedi günden uzun olması ve meropenem kullanım öyküsünün olması çok değișkenli analizde anlamlı bulunmuștur [16] $\mathrm{Bu}$ sonuçlar doğrultusunda bizim çalıșmamızda da literatür ile benzer sonuclara ulașılmıștır.

Calıșmamızda rektal tarama öncesi antibiyotik kullanımının VRE kolonizasyonu için bir risk faktörü olduğu ve kolonizasyon riskini 3.21 kat arttırdı̆̆ı belirlendi. Hematoloji, onkoloji, yoğun bakım üniteleri gibi servislerde genis spektrumlu antibiyotikler uzun süre kullanilabilmekte ve VRE bașta olmak üzere dirençli mikroorganizmalarla infeksiyona ve kolonizasyona neden olabilmektedir. Pediatrik hastalarda yapılan 19 çalıșma ve 20334 hastanın değerlendirildiği bir meta-analizde öncesinde vankomisin kullanımının VRE kolonizasyon riskini 4.34; seftazidim kullanımın ise 4.15 kat arttırdığı bildirilmiștir. VRE kolonizasyonunun da takiplerde VRE infeksiyonu gelișmesi riskini 8.75 kat arttırdığı rapor edilmiștir ${ }^{[17]}$. Erișkin YBÜ'de yapilan ve 174 hastada VRE kolonizasyonun değerlendirildiği bir calıșmada da karbapenem kullanımı öyküsü bulunmasının VRE kolonizasyonu riskini 17 kat arttırdığı tespit edilmiștir ${ }^{[18]}$. Üc buçuk yıl süren prospektif bir çalıșmada 1102 hastada risk faktörlerinin değerlendirilmiș, bir günden daha uzun süreli vankomisin ve anti-anaerobik etkili antibiyotik kullanımının VRE kolonizasyonu riskini arttırdı̆̆ı; antibiyotik kullanım süresi arttıkça da kolonizasyon riskinin arttığı rapor edilmiștir ${ }^{[19]}$. Kullanılan geniș spektrumlu ve gram-negatiflere etkili antibiyotikler kolon florasında bulunan enterokok gibi gram-pozitif mikroorganizmaların secilmesine; vankomisin ve teikoplanin gibi antibiyotiklerin kullanımı ise bu antibiyotiklere karșı direnc kazanılmasına neden olmaktadır. Ferguson ve arkadașlarıtarafından yapılan bir çalıșmada ilk yılda piperasilin-tazobaktam kullanım oranı 1000 hasta gününde 44 günlük tanıml doz iken ikinci yılda 1000 hasta gününde beșe düșürülmüștür. Bunun sonucunda VRE ile kolonize ve infekte hasta sayıs 191'den 101'e gerilemiștir ${ }^{[20]}$. Gilbert ve arkadașlarının yaptı̆̆ı retrospektif bir çalıșmada da hematoloji-onkoloji ünitelerinde karbapenem kısıtlaması uygulamasının VRE'nin horizontal bulaș riskini azalttığı rapor edilmiștir ${ }^{[21]}$. Bu calıșmalarda olduğu gibi genis spektrumlu antibiyotiklerin kullanımının azaltılması ya da dönüșümlü kullanılması gibi antibiyotik yönetim politikalarının uygulanması
VRE kolonizasyonunun da azalması açısından anlamlı olacaktır.

VRE kolonize ya da infekte hasta ile aynı serviste yatma öyküsünün olması hastalarda VRE kolonizasyonu kazanılması için bir risk faktörü olarak bulunmustur. Ayrica servisler arasında transfer öyküsü bulunmasının da VRE ile kolonize olma riskini arttırdığı sonucuna ulașılmıștır. Her iki sonuç da infeksiyon kontrol önlemlerine uyumda eksiklik olduğunu göstermektedir. Tayvan'dan yapılan ve 7449 hastada VRE rektal kolonizasyonunun değerlendirildiği bir çalıșmada 41 VRE izolatı elde edilmistir. Bu izolatların pulse-field elektroforez ile genomik DNA sekanslaması yapıldığında Enterococcus faecalis izolatlarının coğunun aynı klona ait olduğu görülmüștür. Bu da bu izolatların insandan insana capraz tașınma yolu ile yayıldığını göstermektedir ${ }^{[22]}$. Hematoloji-onkoloji ünitesinde yapilan bir matematiksel modelleme calıșmasında VRE kolonizasyonunda \%31 oranda capraz kontaminasyonun rol oynadığı ve gerekli izolasyon önlemleri uygulandığında ve uyum sağlandığında bu oranın azaltılabileceği rapor edilmiștir [23]. VRE'nin hastadan hastaya tașınmasında sadece infekte ya da kolonize hastaya temas değil hasta çevresi ve esyaları ile temas da bir risk faktörüdür. VRE ile kolonize ya da infekte hastaların taburculuk öncesi ve taburculuk sonrası oda temizlği sonrası ortam kültürleri alınarak karșılaștırma yapılmıștır. Bu çalıșma sonrasında 22 hastanın taburculuğu sonrası 161 ortam kültürü değerlendirildiğinde taburculuk öncesi VRE negatif olan 15 bölge sağlık cal1sanlarının elleri aracılığı ile kontamine olmuș ve ortam temizliği sonrası alınan sürüntü kültüründe VRE pozitif gelmiștir ${ }^{[24]}$. Servisler arası transfer öyküsü fazla olan hastalar sadece sağlık calıșanlarının elleri ile değil sedye, yatak, kapı kolu gibi kontaminasyon ihtimali yuiksek olan yerlerle de temas etmektedir. Gerek sağlık calıșanlarının elleri gerekse infekte ortamlarla temas bu hastalarda VRE ile kolonizasyon ihtimalini arttırmaktadır.

VRE kolonizasyonunda infeksiyon kontrol önlemleri ile ilgili 9 klinik çalısma ile 30949 hastanın değerlendirildiği bir meta-analiz sonucunda standart izolasyon önlemlerinin en bașında bulunan el hijyeni kuralına uyum ile VRE kolonizasyonu riskinin iki kat azaltıldğı sonucuna varılmıștır ${ }^{[25]}$. VRE ile kolonize altı hastanın takip edildiği 80 yataklı bir ünitede el hijyenine uyum ve s1k1 temas izo- 
lasyonu önlemlerinin alınması, antibiyotik kullanım sürelerinin azaltılması ve rektal tarama uygulamasının bașlatılmasını takiben dokuz ay sonra VRE ile kolonize hasta sayısı sıfıra indirilmiștir ${ }^{[26]}$. Fisher ve arkadașları tarafından yapılan bir calıșmada da VRE kolonizasyonunu kontrol altına almak için demet önlemleri uygulanmıstır ${ }^{[27]}$. Bu önlemlerin içinde sürveyans uygulaması, hasta odasına izolasyon kartının asılması, VRE pozitifliğinin otomasyon uyarısı ile bildirilmesi, ortam temizliğinde uygun dezenfektan kullanılması, terminal dezenfeksiyon uygulanması ve ortam temizliğinde floresan ișaretleyicilerin kullanılması yer almıștır. Bu uygulamalar sonrasında Ağustos 2012'de VRE insidansının 1000 bassvuruda 1.5'den Ocak 2015'te 1000 bașvuruda 0.5 'e gerilediği bildirilmiștir. Bu çalıșmanın yapıldığı nefroloji ünitelerinde de VRE kolonizasyon pozitifliği için çapraz tașınma olasılığı yüksek bulunmuștur. Bu nedenle infeksiyon kontrol önlemlerine uyulması VRE pozitifliği insidansının azaltılması açısından önemlidir.

Sonuç olarak uzun süreli ve gereksiz antibiyotik kullanımı enterokoklarda vankomisine karșı direnç gelișmesine neden olabilir. Bu yüzden antibiyotik kullanımında dikkatli olunmalıdır. VRE'li hasta ile aynı serviste yatma ve servisler arası transfer de VRE kolonizasyonu için risk faktörüdür. Bu risk faktörleri göz önünde bulundurulduğunda VRE kolonizasyonunu azaltmak için infeksiyon kontrol önlemlerine uyulması her zaman olduğu gibi önemini korumaktadir.

\section{ETIK KURUL ONAYI}

Calıșma için Erciyes Üniversitesi Klinik Araștırmalar Etik Kurulundan onay alındı (Karar no: 2018/01 Tarih: 12.01.2018).

\section{ÇIKAR ÇATIȘMASI}

Yazarlar bu makale ile ilgili herhangi bir cıkar çatıșması bildirmemișlerdir.

\section{YAZAR KATKISI}

Anafikir/Planlama: AUK, CC,, ZT

Analiz/Yorum: ZT, AUK, CC

Veri Sağlama: CC,, GKU

Yazım: CC, AUK, ZT, GKU

Gözden Geçirme ve Düzeltme: ZT, AUK, GKU

Onaylama: ZT, AUK

\section{KAYNAKLAR}

1. Gao W, Howden BP, Stinear TP. Evolution of virulence in Enterococcus faecium, a hospital-adapted opportunistic pathogen. Curr Opin Microbiol 2018;41:76-82.

2. Rubinstein E, Keynan Y. Vancomycin-resistant Enterococci. Crit Care Clin 2013; 29(4):841-52.

3. Hollenbeck $B L$, Rice $L B$. Intrinsic and acquired resistance mechanisms in Enterococcus. Virulence 2012;3(5):421-33.

4. Atalay S, Ece G, Samlıŏ̆lu P, Maraş G, Köse I, Köse S. Evaluation of vancomycin-resistant Enterococcus cases at a tertiary level hospital in Izmir, Turkey. Mikrobiyol Bul 2012;46(4):553-9.

5. Karki S, Houston L, Land G, Bass P, Kehoe R, Borrell S, et al. Prevalence and risk factors for VRE colonisation in a tertiary hospital in Melbourne, Australia: a cross sectional study. Antimicrob Resist Infect Control 2012;1(1):31.

6. DeLisle S, Perl TM. Vancomycin-resistant Enterococci: a road map on how to prevent the emergence and transmission of antimicrobial resistance. Chest 2003;123:504S-518S.

7. Yang KS, Fong YT, Lee HY, Kurup A, Koh TH, Koh D, et al. Predictors of vancomycin-resistant Enterococcus (VRE) carriage in the first major VRE outbreak in Singapore. Ann Acad Med Singapore 2007;36(6):379-83.

8. Mascini EM, Bonten MJ. Vancomycin-resistant Enterococci: consequences for therapy and infection control. Clin Microbiol Infect 2005;4:43-56.

9. Alotaibi FE, Bukhari EE. Emergence of Vancomycin-resistant Enterococci at a Teaching Hospital, Saudi Arabia. Chin Med J (Engl)2017;130(3):340-6.

10. Prematunge C, MacDougall C, Johnstone J, Adomako K, Lam F, Robertson J, et al.VRE and VSE bacteremia outcomes in the era of effective VRE therapy: a systematic review and meta-analysis. Infect Control Hosp Epidemiol 2016;37(1):26-35.

11. Arda B, Yamazhan T, Aydemir F, Tünger A, Özinel MA, Ulusoy S. Vankomisine dirençli Enterokok epidemisi Ege Üniversitesi Tıp Fakültesi deneyimi. Hastane Infeksiyonları Dergisi 2002;6:202-6.

12. Kılıç FK, Çalkavur Ş, Olukman Ö, Ercan G, Oruç Y, Özkök D, ve ark. Management of vancomycin-resistant Enterococci colonization in a neonatal intensive care unit: lessons from an outbreak. Behcet Uz Cocuk Hast Derg 2012;2(3):14853.

13. Wayne (PA). Clinical and Laboratory Standards Institute. Performance standards forantimicrobial susceptibility testing; twenty-third informational supplement. CLSI document (M100-S23). National Committee for Clinical Laboratory Standards; 2013.

14. Skjøt-Arkil H, Mogensen CB, Lassen AT, Johansen IS, Chen $M$, Petersen $P$, et al. Carrier prevalence and risk factors for colonisation of multiresistant bacteria in Danish emergency departments: a crosssectional survey. BMJ Open 2019;9(6):e029000. 
15. Kampmeier S, Kossow A, Clausen LM, Knaack D, Ertmer $C$ Gottschalk $A$, et al. Hospital acquired vancomycin resistant Enterococci in surgical intensive care patients - a prospective longitudinal study. Antimicrob Resist Infect Control 2018;7:103.

16. Karki S, Houston L, Land G, Bass P, Kehoe R, Borrell S, et al. Prevalence and risk factors for VRE colonisation in a tertiary hospital in Melbourne, Australia: a cross sectional study. Antimicrob Resist Infect Control 2012;1(1):31.

17. Flokas ME, Karageorgos SA, Detsis M, Alevizakos M, Mylonakis $E$. Vancomycin-resistant Enterococci colonisation, risk factors and risk for infection among hospitalised paediatric patients: a systematic review and meta-analysis. Int J Antimicrob Agents 2017;49(5):565-72.

18. Batistão DW, Gontijo-Filho PP, Conceição N, Oliveira AG, Ribas RM. Risk factors for vancomycin-resistant Enterococci colonisation in critically ill patients. Mem Inst Oswaldo Cruz 2012; 107(1):57-63.

19. Chanderraj R, Millar JA, Patel TS, Read AF, Washer L, Kaye $K S$, et al. Vancomycin-resistant Enterococcus acquisition in a tertiary care hospital: testing the roles of antibiotic use, proton pump inhibitor use, and colonization pressure. Open Forum Infect Dis 2019;6(4):26-7.

20. Ferguson JK, Munnoch SA, Kozierowski K, Chiu S, Oldmeadow C. Reduced VRE and MRSA colonisation and infection following sustained reduction in broad spectrum antibiotic use in a large tertiary hospital. Med J Aust 2019;20(1):19.

21. Gilbert EM, Zembower TR, Rhodes NJ, Qi C, Reiner S, Malczynski $M$, et al. Factors contributing to vancomycin-resistant Enterococcus spp. horizontal transmission events: exploration of the role of antibacterial consumption. Diagn Microbiol Infect Dis 2017;89(1):72-7.

22. Chang CM, Wang LR, Lee HC, Lee NY, Wu C), Ko WC. Characterisation of vancomycin-resistant Enterococci from hospitalised patients at a tertiary centre over a seven-year period. J Hosp Infect 2010;74(4):377-84.
23. Cheah $A$, Cheng $A C$, Spelman $D$, Nation $R L$, Kong $D$, McBryde ES. Mathematical modelling of vancomycin-resistant Enterococci transmission during passive surveillance and active surveillance with contact isolation highlights the need to identify and address the source of acquisition. BMC Infect Dis 2018;18(1): 511

24. Duckro AN, Blom DW, Lyle EA, Weinstein RA, Hayden MK. Transfer of vancomycin-resistant Enterococci via health care worker hands. Arch Intern Med 2005;65(3):302-7.

25. De Angelis G, Cataldo MA, De Waure C, Venturiello S, La Torre G, Cauda R, et al. Infection control and prevention measures to reduce the spread of vancomycin-resistant Enterococci in hospitalized patients: a systematic review and meta-analysis. J Antimicrob Chemother 2014;69(5):118592.

26. Jehl C, Vogel T, Lavigne T, Hitti A, Berthel M, Kaltenbach $G$. Effectiveness of "contact" precautions to prevent the spread of vancomycin resistant Enterococci in a long-term care facility. Presse Med 2011;40(7-8):325-32.

27. Fisher D, Pang L, Salmon S, Lin RTP, Teo C, Tambyah P. SuCcessful vancomycin-resistant Enterococci reduction bundle at a Singapore Hospital. Infect Control Hosp Epidemiol 2015;37(01):107-9.?

\section{Yazıșma Adresi/Address for Correspondence}

Dr. Öğr. Üyesi ZEYNEP TÜRE

Erciyes Üniversitesi Tıp Fakültesi Hastanesi,

İnfeksiyon Hastalıkları ve Klinik Mikrobiyoloji Kliniği,

Kayseri-Türkiye

E-posta: dr.zeynepture@gmail.com 